\title{
Potential Human Health Risk Assessment of Heavy Metals Intake via Consumption of some Leafy Vegetables obtained from Four Market in Lagos Metropolis, Nigeria
}

\section{*11ADEDOKUN, ADERINOLA HANNAH; NJOKU, KELECHI LONGINUS; AKINOLA, MODUPE OLATUNDE; "ADESUYI, ADEOLA ALEX; JOLAOSO, ANUOLUWAPO OMOSILEOLA}

\author{
Environmental Biology Research Unit, Cell Biology and Genetics Department, \\ University of Lagos, Akoka, Lagos, Nigeria \\ *Correspondence Email: biologistalex@gmail.com
}

\begin{abstract}
This work investigated six heavy metals ( $\mathrm{Pb}, \mathrm{Cr}, \mathrm{Zn}, \mathrm{Cd}, \mathrm{Ni}$ and $\mathrm{Cu})$ accumulation in five popular leafy vegetables: Telferia occidentalis (fluted pumpkin), Talinum triangulare (waterleaf), Ocimum gratissimum (scent leaves), Celosia argentea (plumed cockscomb), and Amaranthus viridis (slender amaranth) obtained from 4 popular markets in Lagos metropolis using an atomic absorption spectrophotometer (AAS), and evaluate the human health risks of their consumption. Heavy metals content in vegetables across the markets ranged as follow; $\mathrm{Cd}(0.05-$ $0.20 \mathrm{mg} / \mathrm{kg}) ; \mathrm{Pb}(0.34-5.44 \mathrm{mg} / \mathrm{kg}), \mathrm{Zn}(4.21-20.80 \mathrm{mg} / \mathrm{kg}), \mathrm{Cr}(0.25-1.51 \mathrm{mg} / \mathrm{kg}), \mathrm{Ni}(0.13-$ $2.91 \mathrm{mg} / \mathrm{kg})$ and $\mathrm{Cu}(2.34-14.08 \mathrm{mg} / \mathrm{kg})$. The concentrations of all metals are quite generally lower than the permissible levels by FAO/WHO in vegetables except for Pb. Statistical analysis of levels of the studied metals in A. viridis, T. occidentalis, $C$. argentea, and O. gratissimum in all the markets sample showed significant differences in levels of $\mathrm{Zn}, \mathrm{Cr}, \mathrm{Cu}$ and $\mathrm{Ni}(\mathrm{p}<0.05)$. To assess the the health risk of the inhabitants of Lagos and the environs due to heavy metal intake from these vegetables consumption., the daily intake of metals (DIM), health risk index (HRI), and target hazard quotient (THQ) were calculated. The daily intake of metals in vegetables species for $\mathrm{Zn}(0.51-1.46 \mathrm{mg} / \mathrm{kg})$ and $\mathrm{Ni}(0.05-0.22 \mathrm{mg} / \mathrm{kg})$ are significantly lower than the recommended daily intake of metals and the upper tolerable daily intake level (UL). However, DIM of Cd $(0.004-0.017 \mathrm{mg} / \mathrm{kg})$ and $\mathrm{Pb}(0.046-0.182 \mathrm{mg} / \mathrm{kg})$ exceed the recommended DIM but fall within the upper tolerable daily level. $\mathrm{Cr}(0.048-0.082 \mathrm{mg} / \mathrm{kg})$ is lower than the recommended oral reference dose (RFD) of $1.5 \mathrm{mg} / \mathrm{kg}$ (USEPA, 2010). The THQ values range showed that $\mathrm{Cd}$ was $0.048-0.192, \mathrm{~Pb}$ was $0.150-0.587, \mathrm{Zn}$ was $0.021-0.190, \mathrm{Cr}$ was $0.0001-$ $0.001, \mathrm{Ni}$ was $0.050-0.120$ and $\mathrm{Cu}$ was $0.148-0.239$. This result reflected the risk associated with exposure for the period of life expectancy considered, and the inhabitants are highly exposed to health risks associated to these metals in the order $\mathrm{Pb}>\mathrm{Cu}>\mathrm{Cd}>\mathrm{Ni}>\mathrm{Zn}>\mathrm{Cr}$. The THQ in all metals is less than 1 in all the vegetables species; therefore, it does not pose serious health risk concern. However, vegetable consumption was just one part of food consumption, the potential health risks for residents might actually be higher than in this study when other routes of heavy metals intake are considered. CJASEM
\end{abstract}

http://dx.doi.org/10.4314/jasem.v20i3.6

Key Words: Heavy Metals, leafy vegetable, daily intake of metals, health risk index, target hazard quotient (THQ), zinc, lead, chromium, cadmium, nickel, copper

A general concern about the safety of foods has been on the increase in recent years (Hansen et al., 2002; Gyawali et al., 2011). The concentrations of natural and synthetic chemical compounds in food contribute to its safety, it is therefore necessary to quantify the traditional nutrients, heavy metals, pesticides and various other constituents for the safety of consumers (Hansen et al., 2002). Improving the nutritional quality of food is imperative for farmers and food industries. Vegetables are edible plants or parts of a plant; they are those herbaceous plants whose part or parts are eaten as supporting food or main dishes and they may be aromatic, bitter or tasteless (Mensah et al., 2008). The utilization of leafy vegetable is part of Africa's cultural heritage and they play important roles in the customs, traditions and food culture of the African household (Mensah et al., 2008). Nigeria is endowed with a variety of traditional vegetables and different types are consumed by the various ethnic groups for different reasons. The nutrient content of different types of vegetables varies considerably and they are not major sources of carbohydrates compared to the starchy foods which form the bulk of food eaten, 
but contain vitamins, essential amino acids, as well as minerals and antioxidants (Fasuyi, 2006).

Human beings are encouraged to consume more vegetables and fruits, which are a good source of vitamins, minerals, fiber and are beneficial for health (Khairiah et al., 2004). However, these plants contain both essential and toxic metals over a wide range of concentrations (Khairiah et $a l .$, 2004). It is well known that plants take up metals by absorbing them from contaminated soil as well as from deposits on parts of the plants exposed to the air from polluted environments (Khairiah et al, 2004; Sobukola et al., 2009). The safety of vegetables and other food crops cultivated for human consumption have been an issue of public concern due to pollution (Chiroma et al., 2003).

Heavy metals are generally used to describe chemical elements with a specific gravity that is at least 5 times the specific gravity of water; the specific gravity of water is 1 at $4^{\circ} \mathrm{C} / 39^{\circ} \mathrm{F}$ (Lide, 1992). Anthropogenic activities such as; transportation, burning of fossil fuel, construction and manufacturing increase the concentrations of heavy metals in the soils and in some plants (Adesuyi et al., 2015; Adesuyi et al., 2016). Other sources of anthropogenic contamination include the addition of manures, sewage sludge, fertilizers and pesticides to soils, with a number of studies identifying the risks in relation to increased soil metal concentration and consequent crop uptake (Kachenko and Singh, 2006). Some heavy metals are bio-accumulative in nature in various plant parts, resulting in poor growth of plants (Girisha and Ragavendra, 2006) and pose great danger to the various elements of the food chain in any given environment. Heavy metals such as copper $(\mathrm{Cu})$, zinc $(\mathrm{Zn})$, manganese $(\mathrm{Mn})$ and iron $(\mathrm{Fe})$ are essential in plant nutrition, however many heavy metals do not play a significant role in the plants physiology (Okoronkwo et al., 2005). Plants cultivated in polluted environments can accumulate these toxic metals at a high concentration causing serious risks to human health when consumed. Heavy metals are usually absorbed by plants through their growth media (air, soil, nutrients, to mention a few); plants take up the metals through their roots or foliage (Okoronkwo et al., 2005). The Commission of the European Communities and the Codex Alimentarius Commission (2001) set the Maximum Limit (ML) for Cadmium as $0.2 \mathrm{mg} / \mathrm{kg}$ for leafy vegetables and fresh herbs, $0.1 \mathrm{mg} / \mathrm{kg}$ for stem and root vegetables and 0.05 $\mathrm{mg} / \mathrm{kg}$ for the remaining ungrouped vegetables. For lead, both organizations set the ML of $0.3 \mathrm{mg} / \mathrm{kg}$ for brassicas, leafy vegetables and herbs, and $0.1 \mathrm{mg} / \mathrm{kg}$ for all remaining vegetables. (Kachenko and Singh, 2006).

Considering the potential toxicity, recalcitrant nature and cumulative behaviour of heavy metals, the frequency of vegetables consumption, its safety and health concerns, more research work is still needed to be done on all species of vegetables grown and consumed in Nigeria. Thus, this study was designed to assess the level of some heavy metals in five most consumed vegetable species in Lagos from major markets, and also to assess the potential health risk associated with their daily intake.

\section{MATERIALS AND METHODS}

Sample Collection: Fresh samples of five (5) commonly consumed vegetables were obtained from 4 different markets across Lagos metropolis, Nigeria. The markets are: Ijesha market in Surulere $\left(6^{\circ} 30.064182^{\prime} \mathrm{N} / 3^{\circ} 19.741745^{\prime} \mathrm{E}\right)$, Mile 12 market in Kosofe $\left(6^{\circ} 36.372^{\prime} \mathrm{N} / 3^{\circ} 23.5296^{\prime} \mathrm{E}\right)$, Oja Oba in Alimosho ( $\left.6^{\circ} 38.683346^{\prime} \quad \mathrm{N} / 3^{\circ} 18.320389^{\prime} \mathrm{E}\right)$, and Sura market in Lagos Island ( $6^{\circ} 27.264^{\prime} \mathrm{N} / 3^{\circ} 24.264^{\prime}$ E). The details of the vegetable species, local names and parts of vegetables used for analysis are shown in Table 1 . The samples were properly tagged according to markets in polythene bags and taken to the herbarium of Botany Department, University of Lagos for identification, and subsequently taken to the laboratory for heavy metal analyses.

Table 1: Vegetables used in this study

\begin{tabular}{llllll}
\hline S/n & Botanical name & Common name & Local name & Family & $\begin{array}{c}\text { Parts used/ } \\
\text { consumed }\end{array}$ \\
\hline 1 & Telferia occidentalis & Fluted pumpkin & Ugu & Cucurbitaceae & Stems and leaves \\
2 & Talinum triangulare & Waterleaf & Gbure & Portulaceae & Stems and leaves \\
3 & Ocimum gratissimum & Scent leaf & Efirin & Lamiaceae & Leaves and tender stems \\
4 & Celosia argentea & Plumed cockscomb & Soko & Amaranthaceae & Stems and leaves \\
5 & Amaranthus viridis & Slender amaranth & Tete & Amaranthaceae & Stems and leaves \\
\hline
\end{tabular}


Sample Preparation: The freshly collected raw vegetables were washed up with tap water thoroughly to remove the attached dust particles, soil, unicellular algae, etc. Then they were washed with distilled water and finally with deionized water. The washed vegetables were dried with blotting paper followed by filter paper at room temperature to remove surface water. The vegetables were immediately kept in desiccators to avoid further evaporation of moisture from the materials. After that the vegetables were chopped into small pieces they were oven dried at (55 $\pm 1){ }^{\circ} \mathrm{C}$. Then the vegetables were crushed into fine powder using a porcelain mortar and pestle. The resulting powder was kept in air tight polythene packet at room temperature before being taken to the laboratory for digestion and metals analyses.

Digestion and Metal Analysis: $0.5 \mathrm{~g}$ of each samples was measured into a clean dried beaker $(100 \mathrm{ml}), 10 \mathrm{ml}$ of acidic mixture of $\mathrm{HNO}_{3} / \mathrm{HClO}_{4}$ in ratio 2:1 was then added to the sample for digestion. The samples were allowed to be evenly distributed in the acid by stirring with a glass rod; the beaker was then placed on the digestion block in a fume cupboard for 2 hours at temperature $150^{\circ} \mathrm{C}$ for digestion. The digested samples were then filtered into a $25 \mathrm{ml}$ volumetric flask and made to mark with deionised water. The digested samples were kept at $4{ }^{\circ} \mathrm{C}$ prior to analysis. A Buck scientific atomic absorption spectrophotometer with model 210VGP was used for lead $(\mathrm{Pb})$, chromium $(\mathrm{Cr})$, zinc $(\mathrm{Zn})$, cadmium $(\mathrm{Cd})$, nickel $(\mathrm{Ni})$ and copper $(\mathrm{Cu})$ analysis (MMAF, 2005).

Health risk assessment: The potential health risks of heavy metal consumption through vegetables were assessed based on the daily intake of metal (DIM) (Chary et al., 2008), health risk index (HRI) (Jan et al., 2010), and the target hazard quotient (THQ) (Wang et al., 2005; Storelli, 2008). The daily intake of metals (DIM) was calculated to averagely estimate the daily metal loading into the body system of a specified body weight of a consumer. This will inform the relative phyto-availability of metal. This does not take into cognizance the possible metabolic ejection of the metals but can easily tell the possible ingestion rate of a particular metal. The estimated daily intake of metal in this study was calculated based on the formula below:

$$
=\frac{\text { Cmetal } \times \text { Cfactor } \times \text { Cfoodintake }}{\text { Baverageweight }}
$$

Where, Cmetal is the heavy metal conc. in vegetables $(\mathrm{mg} / \mathrm{kg})$, Cfactor is the conversion factor; Cfoodintake is the daily intake of vegetables. The conversion factor of 0.085 is to convert fresh vegetable weight to dry weight (Sajjad et al., 2009), daily vegetable intake of $65 \mathrm{~g} /$ day (Oguntona, 1998) while the average body weight used was $65 \mathrm{~kg}$ for this study (Oguntona, 1998).

The health risk index (HRI) was calculated using the formula below:

$$
H R I=\frac{D I M}{\mathrm{RFD}}
$$

The THQ was calculated using the formula below:

$$
T H Q=\frac{\mathrm{EF} \times \mathrm{ED} \times \mathrm{FIR} \times \mathrm{C}}{\mathrm{RFD} \times \mathrm{WAB} \times \mathrm{TA}} \times 10^{-3}
$$

where $\mathrm{EF}$ is the exposure frequency (350 days/year); $\mathrm{ED}$ is the exposure duration (54 years, equivalent to the average lifetime of the Nigerian population); FIR is the food ingestion rate (vegetable consumption values for south western adult Nigerian is 65 $\mathrm{g} /$ person/day) (Oguntona, 1998); $\mathrm{C}$ is the metal concentration in the edible parts of vegetables $(\mathrm{mg} / \mathrm{kg}) ; \mathrm{RFD}$ is the oral reference dose $(\mathrm{Pb}, \mathrm{Cd}, \mathrm{Cu}$, $\mathrm{Zn}, \mathrm{Cr}$ and $\mathrm{Ni}$ values were $0.0035,0.001,0.040$, $0.300, \quad 1.5$ and $0.020 \mathrm{mg} / \mathrm{kg} /$ day, respectively) (USEPA IRIS, 2006); WAB is the average body weight (65 kg for adults vegetable consumer in South western Nigeria) (Oguntona, 1998); and TA is the average exposure time for non-carcinogens (ED x 365 days/year). If the THQ value is greater than 1 , the exposure is likely to cause obvious adverse effects.

Statistical analyses: Collected data obtained from various parameters of vegetable samples were subjected to mean \pm standard deviation (SD). One way analysis of variance (ANOVA) was used to determine significant difference $(\mathrm{p}<0.05)$ between groups using Graph pad prism, version 5.0.

\section{RESULTS AND DISCUSSION}

Levels of heavy metals in vegetable samples: Various sources of environmental contamination have been implicated as route for heavy metals in food. Waste water irrigation, air deposition, spillage are major pathway to heavy metals bioaccumulation in vegetables and plants (Singh et al., 2010; Oluwole et al., 2013; Adesuyi et al., 2015). Vegetable is a major part of Nigerian diet and is very susceptible to environmental pollution due to the activities and 
processes going on or practiced in the area where it is cultivated or obtained from. The recommended maximum limit of cadmium, chromium, lead and copper for vegetables by FAO/WHO 2001 is $0.2,2.3$, 0.3 and $40 \quad(\mathrm{mg} / \mathrm{kg})$ respectively (Maleki and Zarasvand, 2008). The Chinese Department of Protective Medicines 1994 has the safe limit for lead in vegetable as $0.2 \mathrm{mg} / \mathrm{kg}$ and $20 \mathrm{mg} / \mathrm{kg}$ for Zinc (Asdeo and Loonker, 2011). The recommended limits for various heavy metals vary depending on the food being considered and the country sometimes or the organisation. While we find safe limits of heavy metals documented by health sectors in some countries other countries do not have an available document to guide the heavy metal consumption of its citizens. The results obtained from the vegetable samples collected from the various markets around Lagos state for $\mathrm{Cd}$, $\mathrm{Pb}, \mathrm{Zn}, \mathrm{Cr}, \mathrm{Ni}$ and $\mathrm{Cu}$ are shown in tables 2, 3, 4 and 5.

Table 2: Heavy metal concentrations in Ijeshatedo Market ( $\mathrm{mg} / \mathrm{kg})$

\begin{tabular}{lcccccc}
\hline Vegetables & $\mathrm{Cd}$ & $\mathrm{Pb}$ & $\mathrm{Zn}$ & $\mathrm{Cr}$ & $\mathrm{Ni}$ & $\mathrm{Cu}$ \\
\hline A. viridis & $\mathrm{ND}$ & 0.50 & 16.95 & $\mathrm{ND}$ & 0.50 & 11.41 \\
C. argentea & $\mathrm{ND}$ & 0.34 & 15.91 & $\mathrm{ND}$ & 0.74 & 10.19 \\
O. gratissimum & $\mathrm{ND}$ & $\mathrm{ND}$ & 7.70 & $\mathrm{ND}$ & 2.35 & 6.90 \\
T. triangulare & $\mathrm{ND}$ & $\mathrm{ND}$ & 5.53 & 0.39 & 0.83 & 4.08 \\
$T$. occidentalis & $\mathrm{ND}$ & $\mathrm{ND}$ & 4.21 & $\mathrm{ND}$ & 0.40 & 13.90 \\
\hline
\end{tabular}

Table 3: Heavy metal concentrations in Mile 12 Market (mg/kg)

\begin{tabular}{lcccrrl}
\hline Vegetables & $\mathrm{Cd}$ & $\mathrm{Pb}$ & $\mathrm{Zn}$ & $\mathrm{Cr}$ & $\mathrm{Ni}$ & $\mathrm{Cu}$ \\
\hline A. viridis & $\mathrm{ND}$ & $\mathrm{ND}$ & 13.65 & 0.25 & 0.39 & 5.43 \\
C. argentea & $\mathrm{ND}$ & $\mathrm{ND}$ & 14.01 & 0.53 & 1.75 & 19.55 \\
O. gratissimum & $\mathrm{ND}$ & 0.513 & 4.89 & 0.33 & 2.88 & 12.28 \\
T. triangulare & ND & $\mathrm{ND}$ & 7.25 & 0.58 & 2.10 & 13.63 \\
T. occidentalis & ND & 0.400 & 8.86 & 0.43 & 0.13 & 2.34 \\
\hline
\end{tabular}

Table 4: Heavy metal concentrations in Oja Oba Market (mg/kg)

\begin{tabular}{lcrrrrr}
\hline Vegetables & $\mathrm{Cd}$ & $\mathrm{Pb}$ & $\mathrm{Zn}$ & $\mathrm{Cr}$ & $\mathrm{Ni}$ & $\mathrm{Cu}$ \\
\hline A. viridis & $\mathrm{ND}$ & 0.49 & 20.80 & 0.64 & 1.16 & 4.73 \\
C. argentea & $\mathrm{ND}$ & 1.08 & 15.39 & 1.10 & 4.15 & 3.96 \\
O. gratissimum & $\mathrm{ND}$ & 0.73 & 7.56 & 1.26 & 2.91 & 8.86 \\
T. triangulare & $\mathrm{ND}$ & 1.18 & 17.89 & 1.33 & 1.55 & 5.49 \\
T. occidentalis & $\mathrm{ND}$ & 1.84 & 5.73 & 1.51 & 2.61 & 6.84 \\
\hline
\end{tabular}

Table 5: Heavy metal concentrations in Oja Oba Market (mg/kg)

\begin{tabular}{lcccccc}
\hline Vegetables & $\mathrm{Cd}$ & $\mathrm{Pb}$ & $\mathrm{Zn}$ & $\mathrm{Cr}$ & $\mathrm{Ni}$ & $\mathrm{Cu}$ \\
\hline A. viridis & 0.05 & 5.44 & 20.80 & 0.81 & 0.28 & 3.06 \\
C. argentea & $\mathrm{ND}$ & 0.88 & 15.39 & 0.53 & 1.49 & 6.15 \\
O. gratissimum & $\mathrm{ND}$ & 0.40 & 7.56 & 0.31 & 1.61 & 7.88 \\
T. triangulare & $\mathrm{ND}$ & 0.96 & 17.89 & 1.34 & 1.90 & 5.08 \\
T. occidentalis & 0.20 & 1.26 & 5.73 & 0.90 & 0.99 & 2.39 \\
\hline
\end{tabular}

ND-not detected

Cd was not detected all the samples except in $A$. viridis $(0.05 \mathrm{mg} / \mathrm{kg})$ and $T$. occidentalis $(0.20 \mathrm{mg} / \mathrm{kg})$ which were both obtained from Sura market. Statistical analysis showed that $\mathrm{Cd}$ concentration in $A$. viridis and $T$. occidentalis in Sura market were significantly different $(\mathrm{p}<0.05)$ from other markets. Cadmium is a heavy metal with high toxicity and it is a non-essential element in foods and natural waters and it accumulates principally in the kidneys and liver (Divrikli et al., 2006; Adesuyi et al., 2015). Higher values have been previously reported for leafy vegetables cultivated along road sides $(0.27 \mathrm{mg} / \mathrm{kg})$ by Oluwole et al (2013). According to FAO/WHO (2001), the safe limit for $\mathrm{Cd}$ consumption in vegetables is $0.2 \mathrm{mg} / \mathrm{kg}$. The concentration of Cadmium in this study is equal to the permissible 
levels by FAO/WHO in vegetable. The most common sources of cadmium in plants and vegetables are sewage sludge application, deposition from fossil fuel combustion, phosphate fertilizers etc (Adesuyi et al., 2015). Cadmium accumulates especially in the kidneys leading to dysfunction of the kidney with increased secretion of e.g. proteins in urine (proteinuri) and other effects (Waalkes, 2000).

The highest level of $\mathrm{Pb}$ was recorded in A. viridis $(5.44 \mathrm{mg} / \mathrm{kg}$ ) obtained in Sura and the least was recorded in $C$. argentea $(0.34 \mathrm{mg} / \mathrm{kg})$ from Ijesha market. There was high variation in $\mathrm{Pb}$ level in all the different vegetables across all sampled market and it was statistically significant $(\mathrm{p}<0.05)$. Lead pollution has been shown to be commensurate with population/vehicular density (Afolami et al., 2010). Generally, lead contaminations occur in vegetables grown on contaminated soils, through air deposition or through sewage sludge/waste water application (Oluwole et al., 2013). Lead poisoning is a global reality, and fortunately is not a very common clinical diagnosis yet in Nigeria except for few occupational exposures (Anetor et al., 1999). In this study, the concentrations of $\mathrm{Pb}$ are quite generally higher than the permissible levels by FAO/WHO in vegetables of $0.3 \mathrm{mg} / \mathrm{kg}$. This is similar to the results obtained by Asdeo and Loonker, (2011), where the $\mathrm{Pb}$ accumulation in vegetables was found to be within the range of $2.32-5.76 \mathrm{mg} / \mathrm{kg}$. The high levels of $\mathrm{Pb}$ in these vegetables may probably be attributed to pollutants in irrigation water, farm soil (farm site) or due to pollution from the highways traffic (Qui et al., 2000; Oluwole et al., 2013). Lower levels of Lead have been reported in Telfaria occidentalis by Akinola and Ekiyoyo (2006). Lead is causing concern in particular due to the possible impacts on children. Lead influences the nervous system, slowing down nervous response. This influences learning abilities and behaviour (Adesuyi et al., 2015).

The highest concentration of $\mathrm{Zn}$ recorded in sampled vegetables was $20.80 \mathrm{mg} / \mathrm{kg}$ in A. viridis obtained from Ojo oba market and the least was $4.21 \mathrm{mg} / \mathrm{kg}$ in T. occidentalis from Ijeshatedo market. A. viridis has a higher bioaccumulation of Zinc across all the markets. Zinc is an essential element in human diet and it is required to maintain the functioning of the immune system. It is also a natural constituent of soils in terrestrial ecosystem and it is taken up actively by roots (Adesuyi et al., 2015). Zn was quite abundant in all the sampled vegetable species but it does not exceed the Chinese Department of Protective
Medicines safe limit in vegetable of $20 \mathrm{mg} / \mathrm{kg}$ (Asdeo and Loonker, 2011). As reported by Ladipo and Doherty (2011) high concentration of zinc in vegetables may lead to vomiting, renal damage, cramps etc.

Cr ranged between $0.25 \mathrm{mg} / \mathrm{kg}$ in A. viridis from Mile 12 market and $1.51 \mathrm{mg} / \mathrm{kg}$ in T. occidentalis from Ojo oba market. Chromium levels in the vegetables sampled are within safe limits of consumption. However the chromium levels obtained from this study are higher than that of Schumacher et al. (1993) where they reported a mean value of $0.1 \mathrm{mg} / \mathrm{kg}$ chromium found in vegetables they worked with. Chromium depending on the valent state can be beneficial or harmful; the hexavalent state of chromium is harmful (Leopora, 2005). Chromium is known to help maintain normal blood glucose levels by enhancing the effects of insulin (Chove et al., 2006). The most widespread human effect is chromium allergy caused by exposure to chromium (especially $\mathrm{Cr}(\mathrm{VI})$ compounds), and they are assumed to cause cancer (RTI, 2000).

O. gratissimum $(2.91 \mathrm{mg} / \mathrm{kg})$ from Ojo oba had the highest Ni content while T. occidentalis $(0.125 \mathrm{mg} / \mathrm{kg})$ from Mile 12 had the least. Nickel is essential for growth and reproduction in livestock and man, but could be carcinogenic in high amount in the body. In this study, Ni content in vegetables was found to be lower than the estimated maximum guideline set by USFDA of 70-80 mg/g (Iwegbue, 2010).

$\mathrm{Cu}$ level of vegetables from these markets ranged between $2.338 \mathrm{mg} / \mathrm{kg}$ in $T$. occidentalis from Mile 12 and $14.075 \mathrm{mg} / \mathrm{kg}$ in $T$. triangulare from Ijesha market. Copper $(\mathrm{Cu})$ is essential to human life as metalloproteins and function as enzymes, however, critical doses leads to health risks such as anemia, diabetes, inflammation, kidney and liver dysfunction and vitamin C deficiency (Lokeshappa et al., 2012). JECFA (2005) suggested safe limits of $40 \mathrm{mg} / \mathrm{kg}$ in adults which was significantly higher than maximum copper levels of vegetables in this study. Although toxicity of copper is rare, its metabolism is enhanced by molybdenum and zinc constituents in the body (Oladele and Fadare, 2015).

Statistical analysis of levels of the studied metals in $A$. viridis, $T$. occidentalis, $C$. argentea, and $O$. gratissimum in all the markets sample showed significant differences in levels of $\mathrm{Zn}, \mathrm{Cr}, \mathrm{Cu}$ and $\mathrm{Ni}$ $(\mathrm{p}<0.05)$. Among all the heavy metals, $\mathrm{Zn}$ 
concentration was the highest and $\mathrm{Cd}$ was the least in all the vegetables. Radwan and Salama (2006) have also found highest concentration of $\mathrm{Zn}$ and lowest of $\mathrm{Cd}$ in vegetables collected from Egyptian markets. The order of concentration in market vegetables is found to be in the order: $\mathrm{Zn}>\mathrm{Cu}>\mathrm{Ni}>\mathrm{Pb}>\mathrm{Cr}>\mathrm{Cd}$.

Health risk assessment: To assess the the health risk of the inhabitants of Lagos and the environs due to heavy metal intake from vegetables consumption., the daily intake of metals (DIM), health risk index (HRI), and target hazard quotient (THQ) were calculated from equations 1, 2, and 3 respectively and the results are presented in Tables 6 and 7. The DIM results in table 6 were compared with the recommended daily intake of metals and the upper tolerable daily intake level (UL) established by the Institute of Medicine for people between the ages of 19 to 70 years (FDA, 2001; Garcia-Rico, 2007). It is very clear from the table that daily intake of metals in vegetables species for $\mathrm{Zn}$ $(0.509-1.458 \mathrm{mg} / \mathrm{kg})$ and $\mathrm{Ni}(0.050-0.22 \mathrm{mg} / \mathrm{kg})$ are significantly lower than the recommended daily intake of metals and the upper tolerable daily intake level (UL). However, DIM of Cd (0.004 - 0.017 $\mathrm{mg} / \mathrm{kg})$ and $\mathrm{Pb}(0.046-0.182 \mathrm{mg} / \mathrm{kg})$ exceed the recommended DIM but fall within the upper tolerable daily level. $\mathrm{Cr}(0.048-0.082 \mathrm{mg} / \mathrm{kg})$ is lower than the recommended oral reference dose (RfD) of $1.5 \mathrm{mg} / \mathrm{kg}$ (USEPA, 2010). A tolerable upper intake level for $\mathrm{Cr}$ has not been established.

\begin{tabular}{|c|c|c|c|c|c|c|}
\hline Vegetables & $\mathrm{Cd}$ & $\mathrm{Pb}$ & $\mathrm{Zn}$ & $\mathrm{Cr}$ & $\mathrm{Ni}$ & $\mathrm{Cu}$ \\
\hline A. viridis & 0.004 & 0.182 & 1.458 & 0.048 & 0.050 & 0.565 \\
\hline C. argentea & 0.00 & 0.066 & 1.186 & 0.061 & 0.182 & 0.913 \\
\hline O. gratissimum & 0.00 & 0.046 & 0.552 & 0.054 & 0.220 & 0.822 \\
\hline T. triangulare & 0.00 & 0.091 & 0.839 & 0.080 & 0.142 & 0.885 \\
\hline T. occidentalis & 0.017 & 0.099 & 0.509 & 0.082 & 0.090 & 0.582 \\
\hline *DI (mg day-1 person -1) & 0.000 & 0.00 & 8 & - & 0.50 & 0.9 \\
\hline *UL (mg day-1 person -1) & 0.064 & 0.240 & 40 & - & 1.00 & 10.00 \\
\hline
\end{tabular}

* Recommended daily intake (DI) and upper tolerable daily intake

(UL) levels of heavy metals in foodstuffs (FDA, 2001; Garcia-Rico, 2007)

The HRI for all the vegetables species ranges as follow; $\mathrm{Cd}(4.0$ - 17.0), Pb (13.14 - 52.0), Zn (1.7 4.86), $\mathrm{Cr}(0.032-0.055)$, and $\mathrm{Cu}(14.125$ - 22.825). The HRI for $\mathrm{Cd}, \mathrm{Pb}, \mathrm{Zn}, \mathrm{Ni}$ and $\mathrm{Cu}$ from this study were far greater than 1 (HRI > 1) except $\mathrm{Cr}$. Generally, HRI $<1$ means that the exposed population is safe of metals health risk while HRI $>1$ means the reverse (Khan et al., 2008). The population is therefore at greater risk of $\mathrm{Cd}, \mathrm{Pb}, \mathrm{Zn}, \mathrm{Ni}$ and $\mathrm{Cu}$ as also reported by Tsafe et al. (2012).

The THQ is a ratio between the measured concentration and the oral reference dose, weighted by the length and frequency of exposure; amount ingested and body weight (Tsafe et al., 2012). The parameter defines the exposure duration and the risk with that period. The THQ values of $\mathrm{Cd}, \mathrm{Pb}, \mathrm{Zn}, \mathrm{Cr}, \mathrm{Ni}$, and $\mathrm{Cu}$ due to vegetable consumption for the populace (adults) of the study area are listed in Table 7. The THQ values range showed that $\mathrm{Cd}$ was $0.048-0.192, \mathrm{~Pb}$ was $0.150-0.587, \mathrm{Zn}$ was $0.021-0.190, \mathrm{Cr}$ was $0.0001-0.001$, Ni was $0.050-0.120$ and $\mathrm{Cu}$ was $0.148-0.239$. This result reflected the risk associated with $\mathrm{Cd}, \mathrm{Pb}, \mathrm{Zn}, \mathrm{Cr}, \mathrm{Ni}$, and $\mathrm{Cu}$ exposure for the period of life expectancy considered, and the inhabitants are highly exposed to health risks associated to these metals in the order $\mathrm{Pb}>\mathrm{Cu}>\mathrm{Cd}>$ $\mathrm{Ni}>\mathrm{Zn}>\mathrm{Cr}$. Generally, $\mathrm{Cu}$ and $\mathrm{Zn}$, which are important nutrients for humans, are considered a much lower health risk to humans than $\mathrm{Pb}, \mathrm{Cd}$, and $\mathrm{As}$ (Alexander et al., 2006). In this study, the THQ in all metals is far less than 1 in all the vegetables species; therefore, it does not pose health risk concern. Higher THQ for $\mathrm{Cd}, \mathrm{Pb}$, and $\mathrm{Ni}$ were reported by Singh et al., (2010) in vegetables from waste water irrigated area. Higher THQ for $\mathrm{Cd}$ and $\mathrm{Pb}$ in an area near a lead $(\mathrm{Pb})$ and antimony ( $\mathrm{Sb}$ ) smelter in Nanning, China, was also reported by Cui et al. (2004) and Zhou et al. (2016) in vegetable species planted in contaminated soils. However, for special populations, such as those with a weak constitution, those that were sensitive, and women that were pregnant, the potential health risks of heavy metal accumulation through vegetable consumption were likely to be higher than for the normal population. Moreover, vegetable consumption was just one part of food consumption. Other foods like fishes, meat, tobacco, rice, and cassava (Osu et al, 2015; Iwegbue, 2015; Jolaoso et al., 2016). For Lagos populace, food consumption, air pollution, drinking water are the important pathways for human exposure to toxic metals (Jolaoso et al., 2016; Njoku et al., 2016). Consequently, the potential health risks for the 
residents were actually higher than the results from this study.

Table 7: Calculated values of health risk index (HRI) and target hazard quotient (THQ) for heavy metals in marketed vegetables

\begin{tabular}{|c|c|c|c|c|c|c|c|c|c|c|c|c|}
\hline \multirow[t]{2}{*}{ Vegetables } & \multicolumn{2}{|c|}{$\mathrm{Cd}$} & \multicolumn{2}{|c|}{$\mathrm{Pb}$} & \multicolumn{2}{|c|}{$\mathrm{Zn}$} & \multicolumn{2}{|c|}{$\mathrm{Cr}$} & \multicolumn{2}{|c|}{$\mathrm{Ni}$} & \multicolumn{2}{|c|}{$\mathrm{Cu}$} \\
\hline & HRI & THQ & HRI & THQ & HRI & THQ & HRI & THQ & HRI & THQ & HRI & THQ \\
\hline A. viridis & 4.00 & 0.048 & 52.00 & 0.587 & 4.860 & 0.055 & 0.032 & 0.001 & 2.50 & 0.072 & 14.125 & 0.148 \\
\hline C. argentea & 0.00 & 0.00 & 18.86 & 0.213 & 3.950 & 0.045 & 0.041 & 0.001 & 9.10 & 0.097 & 22.825 & 0.239 \\
\hline O. gratissimum & 0.00 & 0.00 & 13.14 & 0.150 & 1.840 & 0.021 & 0.036 & 0.001 & 11.0 & 0.120 & 20.55 & 0.215 \\
\hline T. triangulare & 0.00 & 0.00 & 26.00 & 0.293 & 2.800 & 0.032 & 0.053 & 0.001 & 7.10 & 0.076 & 22.125 & 0.232 \\
\hline T. occidentalis & 17.00 & 0.192 & 28.29 & 0.320 & 1.700 & 0.190 & 0.055 & 0.001 & 4.50 & 0.050 & 14.55 & 0.153 \\
\hline
\end{tabular}

Conclusion: Numerous studies have linked excessive bio-accumulation of heavy metals to numerous health abnormalities. They pose both short and long term environmental health risks. Leafy vegetables produced in open-fields or with contaminated irrigation water are known to possess high concentration of heavy metals that pose high risk for healthy living. THQ calculations showed that the THQ in all metals is far less than 1 in all the vegetables species, however if all other routes of entry of heavy metal is considered the potential health risks for residents might actually be higher.

After reviewing the above mentioned studies it may be recommended that: awareness should be raised about the advantages of organic farming and the dangers of heavy metal pollution in order for farmers to adopt best practices for cultivation of vegetables. Waste water irrigation for vegetables and food crops should be discouraged as it serves as the major route for heavy metal accumulation in vegetables. Nigerian food and health agencies should be more proactive in making available limits (minimum and maximum permissible) for contaminants in food to the public.

\section{REFERENCES}

Adesuyi, AA; Ngwoke, MO; Akinola, MO; Njoku, KL; Jolaoso, AO (2016). Physicochemical Assessment of Sediments from Nwaja Creek, Niger Delta, Nigeria. Journal of Geoscience and Environment Protection, 4:16-27.

Adesuyi, AA; Njoku, K.L; Akinola, MO (2015). Assessment of Heavy Metals Pollution in Soils and Vegetation around Selected Industries in Lagos State, Nigeria. Journal of Geoscience and Environment Protection, 3: 11-19.

Afolami, I; Anyakora, C.; Ebuehi, O; Bolawa, O (2010). Lead levels in some edible vegetables in Lagos, Nigeria. Scientific Research and Essays, 5(8): 813-818.
Akinola, MO; Ekiyoyo, TA (2006). Accumulation of lead, cadmium and chromium in some plants cultivated along the bank of river Ribila at Odonla area of Ikorodu, Lagos state, Nigeria. Journal of Environmental Biology, 27(3):597-599.

Alexander, PD; Alloway, BJ; Dourado, AM (2006). Genotypic variations in the accumulation of $\mathrm{Cd}$, $\mathrm{Cu}, \mathrm{Pb}$ and $\mathrm{Zn}$ exhibited by six commonly grown vegetables. Environmental Pollution, 144: 736745.

Anetor JI; Anetor GO; Udah, DC; Adeniyi, FA (2008). Chemical carcinogenesis and chemoprevention: Scientific priority area in rapidly industrializing developing countries African Journal of Environmental Science and Technology, 2(7): 150-156.

Asdeo, A; Loonker, S (2011). A Comparative Analysis of Trace Metals in Vegetables Research Journal of Environmental Toxicology, 5: 125-132.

Chary, NS; Kamala, CT; Raj, DSS (2008). Assessing risk of heavy metals from consuming food grown on sewage irrigated soils and food chain transfer. Ecotoxicology and Environmental Safety, 69: 513-524.

Chiroma, TM; Hymore, FK; Ebawele, RO (2003), Heavy metal contamination of vegetables and soils irrigated with sewage water in Yola, Nigerian Journal of Engineering Research and Development, 2(3): 60-68.

Chove, BE; Ballegu, WR; Chove, LM (2006). Copper and Lead levels in two popular leafy vegetables grown around Morogoro Municipality, Tanzania. Tanzania Health Bulletin, 8(1): 37-40.

Codex Alimentarius Commission (2001). Food additives and contaminants Joint FAO/WHO 
Food Standards programme; ALINORM 01/12A:1-289.

Cui, YJ; Zhu, YG; Zhai, RH; Chen, DY; Huang, YZ; Qui, Y; and Liang, JZ (2004). Transfer of metals from near a smelter in Nanning, China. Environmental International, 30: 785-791.

Divrikli, U; Horzum, N; Soylak, M; Elci, L (2006) Trace heavy metal contents of some spices and herbal plants from western Anatolia, Turkey. International Journal of Food Science and Technology, 41: 712-716.

FAO/WHO (2001). Report on the $32^{\text {nd }}$ Session of the Codex Committee on Food Additives and Contaminants, ALINORM 01/12, Beijing, China, 20-24 March 2000. Joint FAO/WHO Food Standard Programme, Codex Alimentarius Commission, 24 ${ }^{\text {th }}$ Session, 2-7 July, Geneva, Switzerland.

Fasuyi, AO (2006). Nutritional potentials of some tropical vegetable leaf meals: Chemical Characterization and functional properties. African Journal of Biotechnology, 5(1): 49-53.

FDA (Food and Drug Administration) (2001). Dietary Reference Intakes for Vitamin A, Vitamin $K$, Arsenic, Boron,Chromium, Copper, Iodine, Iron, Manganese, Molybdenum, Nickel, Silicon, Vanadium, and Zinc. Report of the Panel on Micronutrients. National Academy Press, Washington, DC Food and Drug Administration, Dietary supplements, Center for Food Safety and Applied Nutrition

Garcia-Rico, L; Leyva-Perez, J; Jara-Marini, ME (2007), Content and daily intake of copper, zinc, lead, cadmium, and mercury from dietary supplements in Mexico. Food Chemistry and Toxicology, 45:1599-1605.

Girisha S.T; Ragavendra V.B (2009). Accumulation of heavy metals in leafy vegetables grown in urban areas by using sewage water and its effect,. Archives of phytopathology and plant protection, 42(10):956 -959.

Gyawali, R; Ibrahim, SA; Abu Hasfa, SH; Smqadri, SQ; Haik, Y (2011), Antimicrobial activity of copper alone and in combination with lactic acid against Escherichia coli $\mathrm{O} 157: \mathrm{H7}$ in laboratory medium and on the surface of lettuce and tomatoes. Journal of Pathogens, 11: 1 - 9.

Hansen, B; Alroe, HF; Kristensen, ES; Wier, M (2002), Assessment of food safety in organic farming, Danish Research Centre for Organic Farming (DARCOF), Working papers, (52):1-24

Iwegbue, CMA (2010). Composition and Daily Intakes of Some Trace Metals from Canned Beers in Nigeria, Journal of Institute of Brewing and Distilling, 116(3): 312-315.

Iwegbue, CMA (2015). Metal concentrations in selected brands of canned fish in Nigeria: Estimation of dietary, intakes and target hazard quotients. Environmental Monitoring Assessment, 187: 1-15.

Jan, FA; Ishaq, M; Khan, S; Ihsanullah, I; Ahmad, I; Shakirullah, M (2010), A comparative study of human health risks via consumption of food crops grown on wastewater irrigated soil (Peshawar) and relatively clean water irrigated soil (lower Dir). Journal of Hazard Materials, 179: 612-621.

JECFA (2005), Joint FAO/WHO Expert Committee on Food additives, $64^{\text {th }}$ Meeting, JECFA/64/SC, Codex Standard 193-1995, Pg. 47, Accessed from: www.codexalimentarius.org on 26th May 2016.

Jolaoso, AO; Njoku, KL, Akinola, MO; Adesuyi, AA; Adedokun, AH (2016), Heavy Metal Analyses and Nutritional Composition of Raw and Smoked Fishes from Ologe and Lagos Lagoon, Lagos, Nigeria, Journal of Applied Science and Environmental Management, 20(2): In press.

Kachenko, A.E and Singh, B. (2006), Heavy Metals Contamination in Vegetables grown in Urban and Metal Smelter contaminated sites in Australia. Water, Air and Soil Pollution, 169:101 - 123.

Khairiah, J; Zalifah, MK; Yin, YH; Aminah, A (2004). The uptake of Heavy Metals by Fruit type Vegetables grown in selected Agricultural Areas. Pakistan Journal of Biological Sciences, 7(8): 1438-1442.

Khan, S; Lin, A; Zhang, S; Huc, Q; Zhu, Y. (2008), Accumulation of polycyclic aromatic hydrocarbons and heavy metals in lettuce grown 
in the soils contaminated with long-term waste water irrigation. Journal of Hazardous Material, 152: 506-515.

Ladipo, KM; Doherty, VF (2011), Heavy metal levels in vegetables from selected markets in Lagos, Nigeria, African Journal of Food Science and Technology, 2(1): 18-21.

Lide, DR (1992). CRC Handbook of Chemistry and Physics, A ready-reference book of chemical and physical data. $73^{\text {rd }}$ ed. CRC Press, Boca Raton. $2472 \mathrm{pp}$

Lokeshappa, B; Shivpuri, K; Tripathi, V; Dikshit, AK (2012), Assessment of Toxic Metals in Agricultural Produce, Food and Public Health, 2(1): 24-29.

Maleki, A; Zarasvand, MA (2008), Heavy Metals in Selected Edible Vegetables and Estimation of their Daily Intake in Sanandaj, Iran, The Southeast Asian Journal of Tropical Medicine and Public Health, 39(2): 335 - 340.

Manual of Methods of Analysis of Foods-metals (MMAF) (2005), Manual of methods of Analysis of Foods, Oils and Fats. Directorate General of Health Services, Ministry of Health and Family Welfare, Government of India, New Delhi. 114pp.

Mensah, JK; Okoli, RI; Ohaju-Obodo, JO; Eifediyi, K (2008). Phytochemical, nutritional and medical properties of some leafy vegetables consumed by Edo people of Nigeria, African journal of Biotechnology, 7(14): 2304-2309.

Njoku, KL; Rumide, TJ; Akinola, MO; Adesuyi, AA; Jolaoso, AO (2016). Ambient Air Quality Monitoring in Metropolitan City of Lagos, Nigeria, Journal of Applied Science and Environmental Management, 20(1): 178-185.

Oguntona, T (1998). Green Leafy Vegetables. In: Osagie, A.U. and O.U. Eka (Eds.). Nutritional Quality of Plant Foods. Post Harvest Research Unit, Department of Biochemistry, University of Benin, Benin City, Nigeria, pp: 120-133. ISBN: 978-2120-02-2.

Okoronkwo, NE; Igwe, JC; Onwuchekwa, EC (2005). Risks and health implications of polluted soils for Crop production, African Journal of Biotechnology, 4(13): 1521 - 1524.
Oladele, AT; Fadare, OO (2015). Heavy metals and proximate composition of forest leafy vegetables in oil producing area of Nigeria, Ethiopia Journal of Environmental Studies and Management, 8(4):451-463.

Oluwole, SO; Makinde, OSC; Yusuf, KA; Fajana, OO; Odumosu, AO (2013), Determination of Heavy Metal Contaminants in Leafy Vegetables Cultivated By the Road Side, International Journal of Engineering Research and Development, 7(3):1-5.

Osu, SR; Solomon, MM; Abai, EJ; Etim, IG (2015). Human health risk assessment of heavy metals Intake via cassava consumption from crude oil impacted soils with and without palm bunch ash additive, International Journal of Technical Research and Applications, 3(4):140-148.

Radwan, MA; Salama, AK (2006), Market based survey for some heavy metals in Egyptian fruits and vegetables. Food and Chemical Toxicology 44: $1273-1278$.

RTI (2000), Toxicological profile for chromium, Syracuse Research Corporation for U.S. Department of Health and Human Services, Agency for Toxic Substances and Disease Registry, Atlanta

Singh, A; Sharma, RK; Agrawal, M; Marshall, FM (2010), Risk assessment of heavy metal toxicity through contaminated vegetables from waste water irrigated area of Varanasi, India. Tropical Ecology, 51(2S): 375-387.

Sobukola, OP; Adeniran, OM; Odedairo, AA; Kajihausa, OE (2010), Heavy metal levels of some fruits and leafy vegetables from selected markets in Lagos, Nigeria. African Journal of Food Science, 4(2): 389 - 393.

Storelli, MM (2008). Potential human health risks from metals $(\mathrm{Hg}, \mathrm{Cd}$, and $\mathrm{Pb})$ and polychlorinated biphenyls (PCBs) via seafood consumption: Estimation of target hazard quotients (THQs) and toxic equivalents (TEQs). Food Chemistry and Toxicology, 46: 2782-2788.

Tsafe AI; Hassan, LG; Sahabi, DM; Alhassan, Y; Bala BM (2012), Evaluation of Heavy Metals Uptake 
and Risk Assessment of Vegetables Grown in Yargalma of Northern Nigeria. Journal of Basic and Applied Science Research, 2(7): 6708-6714.

US-EPA IRIS (2006). United States, Environmental Protection Agency, Integrated Risk Information System. <http://www.epa. Gov/iris/subst>.

USEPA (2010), Integrated Risk Information System (IRIS), United States Environmental Protection. Available online:

http://www.epa.gov/iris/index.html (accessed on 4 May 2016).

Waalkes, MP (2000). Cadmium carcinogenesis in review, Journal of Inorganic Biochemistry, 79: 240-244.
Wang, X; Sato, T; Xing, B; Tao, S (2005), Health risks of heavy metals to the general public in Tianjin, China via consumption of vegetables and fish. Science and Total Environment, 350: 28-37.

Zhou, H; Yang, W; Zhou, X; Liu, L; Gu, JF; Wang, WL; Zou, JL; Tian, T; Peng, PQ; Liao, BH (2016). Accumulation of Heavy Metals in Vegetable Species Planted in Contaminated Soils and the Health Risk Assessment. International Journal of Environmental Research and Public Health, 13: 289-291. 